Volume 7, Issue 1, 1-3 Pages

Research Article | Open Access

ISSN (Online)- 2378-9026

DOI :

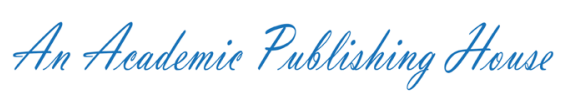

\title{
A Conspectus of Gender Bias: Instances from the Major Works of Mulk Raj Anand
}

\author{
Dr. K. G. B.Santhosh Kumari ${ }^{1}$, Dr. I. S. V. Manjula ${ }^{2}$
}

Assoc. Professor, Dept. of BS\&H, Vignan's Institute of Information Technology (Autonomous), Visakhapatnam. Professor of English and International Examiner, Guest Faculty- BITS Pilani (WILP)

\begin{abstract}
This paper highlights the problems faced by women in $20^{\text {th }}$ century by citing the examples from the novels of Mulk Raj Anand. The gender bigotry in the patriarchal society of colonial India, in particular, is deftly portrayed by Anand through his characters. The atrocities of the male characters like Reggie and the suffering of female characters like Sohini,Gauri,Rukmini allow the readers to get a realistic perception of the days of colonial era, particularly in the lower strata of society working in the tea plantation that were governed ruthlessly by the colonial representatives. The novels of Anand are a record of the social conditioning of the working class women and men of those days.
\end{abstract}

KEYWORDS: Gender-female characters in Mulk Raj Anand Novels-criticism in society-treatment of women.

Gender' is a psychological and cultural term. It denotes socially constructed roles, behaviors, activities, and attributes that a particular society considers apt for men and women. It is decided by cultural, social, political and economic forces which influence social behavior of men and women." 1 The gender difference is the foundation of a structural inequality between a man and woman. The discrimination based on the gender of a person is perpetuated through the socio-cultural and psychological mechanisms prevalent in society. This paper highlights the problems faced by women in $20^{\text {th }}$ Century and the present trend by citing the examples from the novels of Mulk Raj Anand.

As the Sanskrit sloka "Yatra Naryantu Pujyante tatra ramante devatah" says, where there is respect for women, there will be prosperity. Mulk Raj Anand is one of the prominent writers in the saga of Indian Writing in English who highlighted this concept in his works meticulously. In many novels of Anand, the current scenario is projected in a more picturesque style. In reality, a person is considered good or bad based on the circumstances, the place of his or her growth and financial status.

In his novels, Anand shows various characters of women who are suppressed and humiliated in the patriarchal society. He portrays the socio-religious hypocrisy rampant in various walks of society. In Anand's Two Leaves and a Bud, the coolie women faced various problems in the hands of the English. The plantation masters or sahibs molest the coolie women, irrespective of their age. "The Coolie women bent to their plucking with fear in their hearts and a queer confusion in their heads" ( $\mathrm{p} \mathrm{50})^{2}$. Reggie felt that "The women workers are more efficient, Reggie assured himself, quite insensitive to the under currents of emotion he had let loose in their souls. He favored them almost involuntarily, hoping to establish a relationship of informal intimacy to facilitate....." ${ }^{3}$ (p50). Anand depicted various scenes where the sexual assault and material wants were evidently shown.

As mentioned earlier, Reggie was attracted by the beauty of women and in the same way, he maintained illicit relation with Neogi's wife also. For Coolie women, there was no one to take care of their babies at their residence. So, they carried their children along with them in the basket. If anyone was unexpectedly caught by the master, she had to face the consequences. Besides severe admonition, a fine of three annas was imposed on her. While scolding the coolie women, Reggie used abusive language like deceitful bitches, dirty cheats, and crafty bitch, and so on.Gangu's daughter

In this novel, Gangu was killed while trying to protect his daughter from being raped by Reggie Hunt, a British colonial official. He was the Assistant planter He was arrogant and sadist who tried to molest Gangu's daughter. Each and every nook and corner of the tea plants leaves and buds are the silent witnesses of Reggie's atrocities. In Two Leaves and a Bud, Narian, a coolie, describes him rightly when he says "He is a very Badmash sahib and he has no consideration for any one's mother or sister. He is openly living with three coolie women!" (42). ${ }^{4}$ 
In The Old Woman and the Cow or Gauri, the character of Gauri symbolizes the suffering of a girl who is harassed by the society. She experienced suffering in various forms. She faced problems as a daughter, wife and a woman in the society. She met Colonel Mahindra who is a doctor and motivator. He encouraged and moulded her which made her the mouth piece of the women who were suffering like her. A lot of transformation is shown in the character of Gauri from a shy and fearful woman to a trend setter. When she was doubted by her husband, she reacts very differently. Anand is successful in aptly projecting her character in the situation. Instead of feeling sorrowful and traumatised, Gauri says to her husband: "If I am a curse on you I will go away...And if you strike me again I will hit you back." [3] $]^{5}$ She compared her husband with Ram who sent Sita to forest for the sake of public opinion. Thus, Anand gave voice and language to woman in the society and was successful in highlighting the women who were supposed to be silent sufferers. Anand said, "Most of my women characters are slaves or semislaves to customs. Only Irene in the Bubble is a free woman, whom the hero loves for the courage". (Interview of Dr. Anand) ${ }^{6}$.

Male domination is inevitable in Gauri. Anand portrays a few characters in his novels, who supports women and motivates them during the time of need and emergency. In this novel, particularly the character of Colonel Mahindra encourages Gauri and through this character Anand shows that there are a few men who stood by women and motivated them to resist suppression. In some of his major novels like Untouchable, Coolie and The Road, Anand emphasizes the idiosyncrasies of women because they are forced to suffer in the predominant class structure, haves and have nots and caste system. Colonial Supremacy and Sexualization of the body play a considerable role in throwing the women down to the bottom of the social hierarchy.

In Untouchable, Bakha looks at his sister, Sohini and observes her beauty and thought in the patriarchal perspective. He felt that his sister attracts many people due to her beauty in spite of wearing torn clothes. Pundit Kali Nath tried to seduce her in the temple and she denied. She was abused by Kalinath who highlighted her caste. He did not think of caste when he wanted to seduce her but when she denied, in order to divert the attention of others, he shouted "polluted". However, Bakha throws the blame partially on Sohini's sensuous attractiveness. Moreover, his feelings for her are also due to his obsession with her body. In fact, Bakha is unable to think of her sexual behavior with her husband, even if she gets married.

In those days, during payment of daily wages of women there was a difference. In The Road, Anand explains about the share of the wages between men and women. However, there is no equal share. The payment of Hari's wife is five rupees compared to a man's wage which is of twenty rupees per month. Anand attributes talent, imagination and determination to women even though they are physically subtle in comparison to men.
After a week while going to the Bazaar, Gangu realizes that they are paid less than what he used to get alone by working on the fields at his village. He censures the white for the exploitation of the poor villagers. Even at the Bazaar the farmers are compelled to sell their produce at cheap rates and buy the essential commodities on high rates. Gangu returns home with high fever. His wife Sajani who represents "the fastidious village women whose whole life had been spent cleaning and washing and cooking and cleaning again," (36) ${ }^{8}$ looks after him. However, she herself gets infected and dies. The epidemic of malaria spreads.

In The Road, Rukmini's mother restricts her daughter and she advises her not to utter even the names of the young men in the village. She is not supposed to wear colourful clothes till her marriage. Boys believed that the girls need to be very 'obedient', 'well behaved', 'calm' and 'quiet'. In Untouchable, Sohini should not show her teeth to men. If any of these norms are violated then that woman's behavior is deemed to befit only a prostitute. Due to this reason, girls became passive and boys became assertive.

Marriage plays a crucial role in the life of any girl. An Indian girl in the lower classes gets married at a very tender age. In Untouchable, Ram Charan's sister gets married at the tender age of fourteen. She is trained to be 'docile', 'well-mannered' and 'gentle' since her childhood. She had to follow the footsteps of her husband. In The Road, Bhagwanti told her daughter that she is no longer a permanent member in the family after she gets married. Thakur Singh, Rukmini's father felt that her daughter cannot serve him during his old age and felt disappointed. Anand portrays a few girl characters which is in contrast the aforementioned concept. In a few stances, marriage brings good fortune to the parents of the bride also. Gulabo received two hundred rupees in return to her daughter's wedding. Gulabo's daughter became an expensive gift to her mother and an expensive possession to her husband.

In Hindu tradition, a woman has to live up to the expectations of her husband in this patriarchal society. The concept of pativrata ideology is also important. A married woman is expected to serve the husband's family members and had to bear male children and in return earns respect. If not, she will be ill-treated in the society. For example, Munoo's aunt in Coolie could not have children for her husband and she lost her recognition in the society. In the male dominated society womanhood is surpassed by motherhood. Thakur Singh, in The Road, agrees to this gender role of a woman and bitterness wells up in him when he finds "that even his wife should dare to talk to him." ${ }^{11}$ According to the Hindu mythology, an ideal woman had to engage herself with the domestic affairs throughout the day.

In Coolie, Munoo's mother continuously worked hard for the well being of the family and experienced a lot of pain which slowly led her to death. While Rukmini, in The Road, expressed the real boredom in the life of a woman who is expected to be a slave for her domestic responsibilities. In 
spite of serving the spouse and her family, she was treated like a slave. Her sacrifices are never and ever recognized.

Unlike Anand, there are various sensuous writers who expressed their feelings on the treatment of women and gender consciousness in their novels. Kamla Das explores the plight of suffering in the day to day life of women. Shashi Desh Pande highlights the pathetic condition of women. Bapsi Sidhwa highlights socio-economic condition of Parsi women. R.K. Narayan highlights the life of house wives in middle class families. Anita Desai deals with the suffering of women. Kamala Markandeya mentions the theme of east-west encounter. Salman Rushdie wrote about sexual abuse of children. Shobha De talks about women who caricatured the traditional life style of women. Indo-Anglian writers portrayed the gender disparity in their own style. Many Indian writers supported the new trend by projecting the social evils that prevail in the patriarchal system. R.K Narayan's The Dark Room is a reflection of this particular scenario in the literary realm. It is one of the earliest novels by an Indian author which dealt with the theme of gender equality and their rights.

Deshpande's highlights 'rape' as one of her major themes which is also featured in Desai's Fire on the Mountain (1977). In Markandaya's Two Virgins (1973), the sense of sexual threat which destroys the lives of young girls in India is poignantly projected. Markandaya in A Handful of Rice (1966), Sahgal in Storm in Chandigarh (1969), Deshpande in That Long Silence (1988) and Desai in Fasting, Feasting (1999) concentrated on the portrayal of domestic violence.

Indian women novelists voiced their opinions which brought a literary renaissance. The third generation of Indian writers in English like Shashi Desh Pande, Gita Mehta, Bharathi Mukherjee, Jhumpha Lahiri Nayantara Sehgal, Anitha Desai, Arundhati Roy brought recognition to this pathetic norm of society in the contemporary literary Scenario. They received national and International acclaims, royalties and awards. The situations created by Anand in his novels regarding the upliftment of women are evident even in $21^{\text {st }}$ century. Every woman feels that she has to be treated properly by getting encouragement. Arundathi Roy, Mrs.Indira Gandhi , Jayalalitha, Kiran Bedi, Saina Nehwal, Hampi, Sania Mirza, Mithali Raj from India and many more proved that women can do justice for personal and professional career. There are many Indian women like Jhansi Lakshmi Bhai, Irom Chanu Sharmila, Chahavi Rajawat, Amrita Devi,Phoolan Devi,Sita Sahu,Chanda Kochhar, Sapper Shanti Tigga, Asha Roy, Arundhati Bhattacharya, Kalpana Chawla, Reena Kaushal
Dharmshaktu, Durga Shakti Nagpal, Kunjarani Devi, Indra Nooyi, who clearly deserve a standing ovation.

Giving credit to Mulk Raj Anand for making his literary world the mirror of contemporary Indian milieu, noted critic Saros Cowasjee observes : "An expositor, a political novelist, Mulk Raj Anand saw his characters and their actions in relation to the social and political upheavals of his time." 12

In Anand's novels, one can see women of the best qualities and the worst qualities. Anand showcases that in certain situations, woman harasses other women for her sadistic pleasure through the characters like Mrs. Todar Mal, Anglo Indian lady, Mrs. Croft Cooke and Neogi's Wife. Anand highlights the problem faced by women through his characters like Parbati, Sohini, Gangu's wife, Lakshmi, daughter of Mr.Croft Cooke, Liela, Janaki, Rukmini. There are some women who overcome the challenges like Gauri in The Old Woman and the Cow and others who succumb to the oppression accepting it as a way of life like Neogi's wife in Two Leaves and a Bud. An interpretation of Anand's novels from the perspective of gender bigotry in society yields a kaleidoscopic view of the lives of women, their travails and their final defeat or victory.

\section{REFERENCES}

1. http://iosrjournals.org/iosr-jhss/papers/Vol19issue6/Version-7/H019674852.pdf

2. Anand, Mulk Raj .Two Leaves and a Bud (New Delhi: Arnold Publishers (India)Pvt Ltd) 1988

3. Ibid

4. Anand, Mulk Raj .Two Leaves and a Bud (New Delhi: Arnold Publishers (India)Pvt Ltd) 1988

5. Anand Mulk Raj,The Old Womam and The Cow, Bombay, Kutub Publication

6. Interview of Dr. Mulk Raj Anand, Dec. 25-27, 2000

7. http://ijmms.in/sites/ijms/index.php/ijmms/article/ viewFile/175/176

8. Anand, Mulk Raj .Two Leaves and a Bud (New Delhi: Arnold Publishers (India)Pvt Ltd) 1988

9. Anand Mulk Raj, The Road, Bombay, Kutub Publication,1961,p.87.

10. Ibid

11. Ibid

12. Saros Cowasjee, Studies in Indian and Anglo-Indian Fiction, (New Delhi : Indus Publishers, 1993) p.36.

Citation: Dr. K. G. B.Santhosh Kumari, Dr. I. S. V. Manjula, "A Conspectus of Gender Bias: Instances from the Major Works of Mulk Raj Anand", American Research Journal of English and Literature, Vol 7, no. 1, 2021, pp. 1-3.

Copyright (C) 2021 Dr. K. G. B.Santhosh Kumari, Dr. I. S. V. Manjula, This is an open access article distributed under the Creative Commons Attribution License, which permits unrestricted use, distribution, and reproduction in any medium, provided the original work is properly cited. 